\title{
Fire management and aspects of the nesting biology of the Red-legged Seriema (Cariama cristata) in woodlands at Parque Nacional das Emas, central Cerrado
}

\author{
Dárius Pukenis Tubelis ${ }^{1,2}$ \\ Departamento de Biociências, Universidade Federal Rural do Semi-Árido, Campus Mossoró, Mossoró, RN, Brazil. \\ 2 Corresponding author: darius.tubelis@gmail.com
}

Received on 20 May 2019. Accepted on 10 December 2019.

\begin{abstract}
In the Brazilian Cerrado Biome, fire management within conservation units is usually restricted to burning grassland and woodland strips during the dry season to stop fires from spreading. Although it is a common practice, the impact of fire management on birds remains poorly investigated. This study aimed to examine the effects of fire management on nest-site selection by the Red-legged Seriema, Cariama cristata, and to describe nest-building characteristics at Parque Nacional das Emas (PNE). Nests were searched and monitored throughout 34 study sites between October and November 2006. These sites were 2.5-km strips of Campo Cerrado woodlands with (firebreaks) and without fire management, located at the interior and boundaries of the park. A total of 13 nests were found, all within firebreaks at the edge of the park. Nine (69\%) of them were in fruiting Pouteria torta (Mart.) (Sapotaceae). Two or three white eggs were found in the nests. Nests had eggs and nestlings in October and no nestlings were found in November. Nests were usually in tree canopies and some of them were built nearly over the park's fence. At PNE, breeding pairs of C. cristata are attracted to firebreaks located at the park's boundaries. This is probably due to mobility through often burnt vegetation and ease in obtaining food from adjacent unsealed roads, exotic plantations and cleared areas. This study suggests that fire managers should: 1) avoid extinguishing natural fires initiated during the rainy season and 2) rotate controlled burning of patchy areas of Campo Cerrado woodlands. These two procedures should ensure the presence of suitable woodlands with short grasses in interior portions of PNE.
\end{abstract}

KEY-WORDS: bird, breeding season, Cariamidae, egg, nest, reproduction, Savanna.

\section{INTRODUCTION}

Fire management for biodiversity conservation is a common practice in several temperate and tropical regions (e.g., Miranda et al. 2009, Bardsley et al. 2019, Phalan et al. 2019). Birds' responses can vary with characteristics of prescribed fires, such as severity, frequency, heterogeneity and season (Greenberg et al. 2019, Zlonis et al. 2019). Fire management may affect birds' abundance and breeding due to changes in the vegetation and associated resources (e.g., O'Loughlin et al. 2019, Ragheb et al. 2019). Studies on avian response to different types of fires have predicted future fire scenarios, thus promoting the conservation of target species (e.g., Connell et al. 2019).

In the Cerrado, a Savanna eco-region in central Brazil, fire management in conservation units usually involves burning woodland and grassland strips almost every year (Miranda et al. 2002, 2004, França et al. 2007). These strips of managed vegetation are firebreaks that lie between two unsealed roads and are settled along borders and in the interior of conservation units (Ramos-Neto \& Pivello 2000, França et al. 2007). Firebreaks usually occur in the dry season to create areas of vegetation with reduced biomass that stop fires from adjacent farmlands (Pivello 2006, França et al. 2007).

Although the impact of fires on the Cerrado flora is well known, information about its influence on many groups of native fauna is lacking (Mistry 1998, Miranda et al. 2004, 2009). Few studies have examined the impacts of natural or accidental fires on bird communities (e.g., Fry 1970, Cavalcanti \& Alves 1997, Cintra \& Sanaiotti 2005), and research on the impact of fire management on particular species is scarce. For example, at Parque Nacional das Emas (PNE), in central Brazil, two investigations showed that Blue-and-yellow Macaws, Ara ararauna, are attracted to grassland and woodland firebreaks. They seek the firebreaks to eat fruits of Cashew-apples Anacardium humile, a species benefited by fire (Tubelis 2009a, b). Further, the only study investigating the influence of fire management on bird reproduction in the Cerrado, also at PNE, has shown that active nests of Burrowing Owls, Athene cunicularia, are more numerous in managed grasslands than in unmanaged patches (Tubelis \& Delitti 2010). However, the influence of fire management within 
Cerrado conservation units is still unknown for most bird species.

This lack of information includes the Red-legged Seriema, Cariama cristata Linnaeus, 1766, a large terrestrial bird species typical of Cerrado landscapes (Antas \& Cavalcanti 1988, Sick 1997). Adults of this species are about $90 \mathrm{~cm}$ high and body mass around $1.5 \mathrm{~kg}$ (Gonzaga 1996, Sick 1997). Their long legs allow them to walk and run on unsealed roads and through non-forest vegetation in landscapes covered by native matrix types, exotic plantations and cleared areas (Miranda-Ribeiro 1937, Redford \& Peters 1986, Brooks 2014). They are territorial animals (Souza et al. 2018) that feed on arthropods, small rodents, lizards and snakes (Gonzaga 1996).

Red-legged Seriemas breed between September and January in Brazil. Nests are round, rough structures composed of sticks and twigs lined with leaves, grasses and clay (Miranda-Ribeiro 1937, Almeida 1994, Silva et al. 2016). Birds usually build nests in trees, $1-5 \mathrm{~m}$ above ground, and lay up to four eggs that are incubated for one month (Redford \& Peters 1986, Almeida 1994, Gonzaga 1996). Red-legged Seriemas inhabit burned and unburned savanna vegetation at PNE (Redford \& Peters 1986), and their responses to fire management remain unstudied. The objective of this study was to investigate the effects of fire management on nest-site selection by C. cristata at PNE. I compared the number of nests in areas of Campo Cerrado woodlands with (firebreaks) and without fire management. I also described characteristics of their nests, eggs, nestlings, plant support for nest building, and nest position in the woodlands. Results are discussed in terms of the influence of fire management on birds in Cerrado conservation units.

\section{METHODS}

\section{Study area}

This study took place at Parque Nacional das Emas (PNE), a 132,000 ha conservation unit in the state of Goiás, central Brazil (Fig. 1). This reserve harbors several vegetation physiognomies commonly found in the Cerrado. Grasslands are the main matrix type, covering mostly flat uplands (França et al. 2007). Another matrix type occurring in uplands is the Campo Cerrado woodland (Eiten 1993). Its herbaceous stratum is also developed but shrubs and trees are more numerous than in grasslands (Eiten 1972, Oliveira-Filho \& Ratter 2002). However, the woody strata are open enough to allow large terrestrial vertebrates to pass through (Antas \& Cavalcanti 1988, Marinho-Filho et al. 2002). Less dominant physiognomies in this park are gallery forests and veredas - wet grasslands with scattered palm trees (França et al. 2007). Further information on Cerrado landscapes can be found in general references about this eco-region (e.g., Eiten 1972, Oliveira \& Marquis 2002, Scariot et al. 2005).

Elevation at PNE ranges between 720 and $900 \mathrm{~m}$ a.s.l. (França et al. 2007). The regional climate is marked by two well-defined periods: the dry season, between May and September; and the rainy season, between October and April. Annual rainfall ranges between 1200 and 2000 $\mathrm{mm}$ and temperatures usually range between $10^{\circ} \mathrm{C}$ in the winter (July) and $40^{\circ} \mathrm{C}$ in the summer (January) (Assad 1994).

At PNE, fires can be natural or human-induced (Redford 1985, França et al. 2007). During the rainy period, natural fires from lightning tend to burn small areas, which are stopped by the rain (Ramos-Neto \& Pivello 2000). Illegal human-induced fires originate on adjacent farms and are used to renew the grassy vegetation for cattle. These fires start during the dry period and can reach the park, where they can spread through extensive portions of the landscape (Ramos-Neto \& Pivello 2000, França et al. 2007). Fire management by park managers is restricted to maintaining the firebreaks, i.e., grassland or woodland strips that usually burn in the dry season (June, July). These procedures avoid fire from spreading to the inner area of the park during the dry season. Firebreaks are located between two unsealed roads and are usually 25-100 m wide (Ramos-Neto \& Pivello 2000, França et al. 2007).

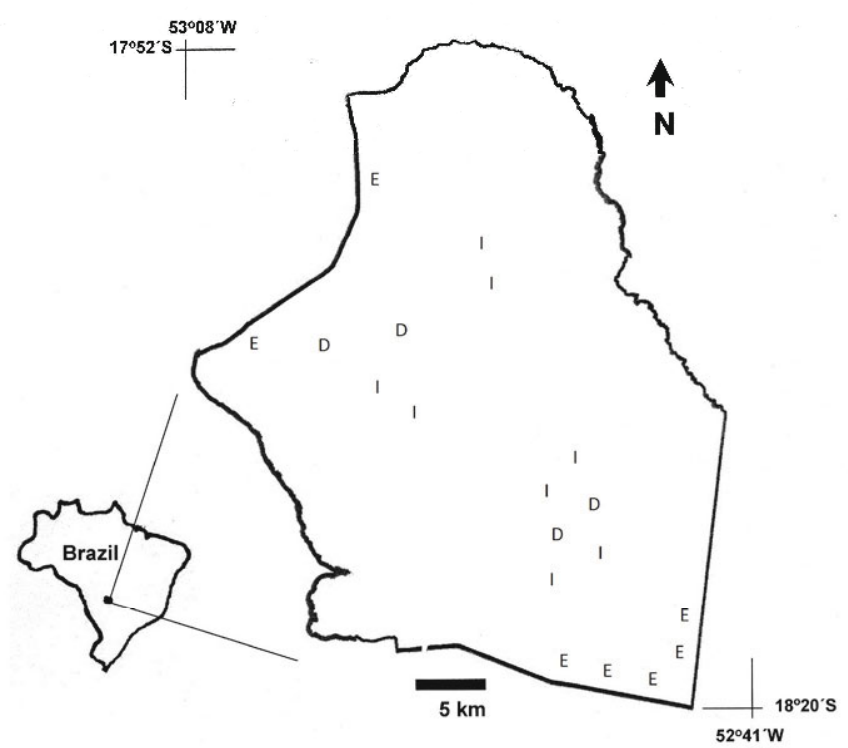

Figure 1. Location of the 34 study sites searched for Cariama cristata nests at Parque Nacional das Emas, in Goiás state, central Brazil, in October and November 2006: (E) pairs of study sites formed by a firebreak and an adjacent unmanaged woodland located at the edge of the park; (I) pairs of study sites formed by a firebreak and an adjacent unmanaged woodland located in the interior of the park; (D) unmanaged woodlands distant from roads and located in the park's interior. 


\section{Study sites}

I selected a total of 34 study sites $(2.5-\mathrm{km}$ long and 30 to $80-\mathrm{m}$ wide transects) at PNE (Fig. 1). These were portions of Campo Cerrado woodlands grouped into five treatments, with a variable number of replicates: 1 ) "edge firebreaks", i.e., fire-managed Campo Cerrado woodland strips adjacent to the park frontier (seven replicates), 2) "adjacent to edge woodlands", i.e., unmanaged Campo Cerrado woodland strips adjacent to the edge firebreaks (seven replicates), 3) "interior firebreaks", i.e., firemanaged Campo Cerrado woodland strips located more than $3 \mathrm{~km}$ away from the park frontiers (eight replicates), 4) "woodlands adjacent to interior firebreaks", i.e., unmanaged Campo Cerrado woodland strips adjacent to interior firebreaks (eight replicates), 5) "distant woodlands", i.e., Campo Cerrado woodland strips more than $3 \mathrm{~km}$ away from the park frontiers and more than $400 \mathrm{~m}$ away from roads (four replicates). Sampled firebreaks and adjacent woodlands were separated by an unsealed road about $7 \mathrm{~m}$ wide. These study sites were spread at least $700 \mathrm{~m}$ apart throughout the park (Fig. 1).

The vegetation of the sampled firebreaks and unmanaged woodlands differed mainly in relation to the height of the grassy stratum. All study sites were dominated by Capim Flexa grass (Tristachya leiostachya Ness.), usually $80-150 \mathrm{~cm}$ high in unmanaged woodlands and 20-30 $\mathrm{cm}$ high in firebreaks (pers. comm.). These differences in vegetation occur because unmanaged woodlands are usually burned every $6-10$ years by natural or accidental fire, while park managers usually burn firebreaks every 1-2 years at PNE (França et al. 2007). Some firebreaks had sparse fully developed Capim Flexa grass, since there was lack of funding for burning.

To ensure the sampling for comparable areas with different treatments, I selected uniform firebreak sections and sampled the same width in adjacent woodlands. The width of firebreaks and adjacent woodland sites ranged between 30 and $70 \mathrm{~m}$. Distant woodland sites were 100 $\mathrm{m}$ wide due to a lower number of replicates, thus, the observer had about $50 \mathrm{~m}$ of woodlands on each side. The length of study sites was determined using a Garmin GPS with an error of $8 \mathrm{~m}$.

\section{Search for nests}

I searched for $C$. cristata nests in the study sites every morning (09:30 h to $11: 00 \mathrm{~h})$ and afternoon $(15: 00 \mathrm{~h}$ to $17: 00 \mathrm{~h}$ ) between 01 and 12 October 2006. Four to eight study sites were searched in a given day. I slowly drove a vehicle along the road between firebreaks and adjacent woodlands. When a high density of fully developed Capim Flexa grass hindered visibility, I would leave the vehicle and enter the woodland to continue the search on foot. After sampling a firebreak, the adjacent woodland was surveyed in the opposite direction. Distant woodlands were always searched on foot, since there were no roads.

Sightings favored large size nests in tree canopies. Every large nest detected was approached on foot to verify whether it was a Seriema nest. Species such as the Aplomado Falcon, Falco femoralis (Temminck, 1822), and the Buff-necked Ibis, Theristicus caudatus (Boddaert, 1783), also build large arboreal nests at firebreaks during this period (Tubelis 2019b). When I approached, adult birds were identified when they flew (falcons and ibises) or ran away (Seriemas) from the nests.

\section{Observations and measurements}

After been found, nests were visited 2-3 times during the search period and once in a second period (between 11 and 14 November 2006) to verify the presence and conditions of eggs and nestlings. This interval of about 30 days between the two periods occurred due to time availability. During each visit to a nest, I used a mirror fixed to a pole to count nestlings and eggs. The distance between the bottom of the nests and the ground was measured with a Bosch laser tape. Additionally, small branches from where nests were built were collected and photographed to identify the plant. I did not measure nests and did not handle nestlings or eggs. On a few occasions, eggs and nestlings were counted and photographed by climbing the tree.

\section{RESULTS}

Thirteen C. cristata nests were found in the 34 study sites located at PNE. All of them were at edge firebreaks, and one $(n=1)$ or two $(n=6)$ nests were found at each of the seven study sites. Thus, no nests were found in interior firebreaks, nor in sites of the three treatments regarding unmanaged woodlands.

Nests were rough and nearly round structures built with diverse materials, such as sticks, twigs and clay (Fig. $2 \mathrm{~A}, \mathrm{~B})$. Eight (61\%) nests contained white eggs with some brownish dust patches (Fig. 2B). Only one nest had three eggs, while seven had two eggs. Another five (39\%) nests had no eggs, but did have two nestlings, when examined for the first time (Table 1). Nestlings were mostly gray, with thin white feathers mainly on the head and belly (Fig. 2C).

On three occasions, adult birds showed aggressive behavior in response to the observer's approach (Fig. 2D), thus nests were not examined. This behavior occurred during the late incubation period, as revealed by examination of the nests a few days later (Table 1). Eggs were found in nests from the second to the last day of the 

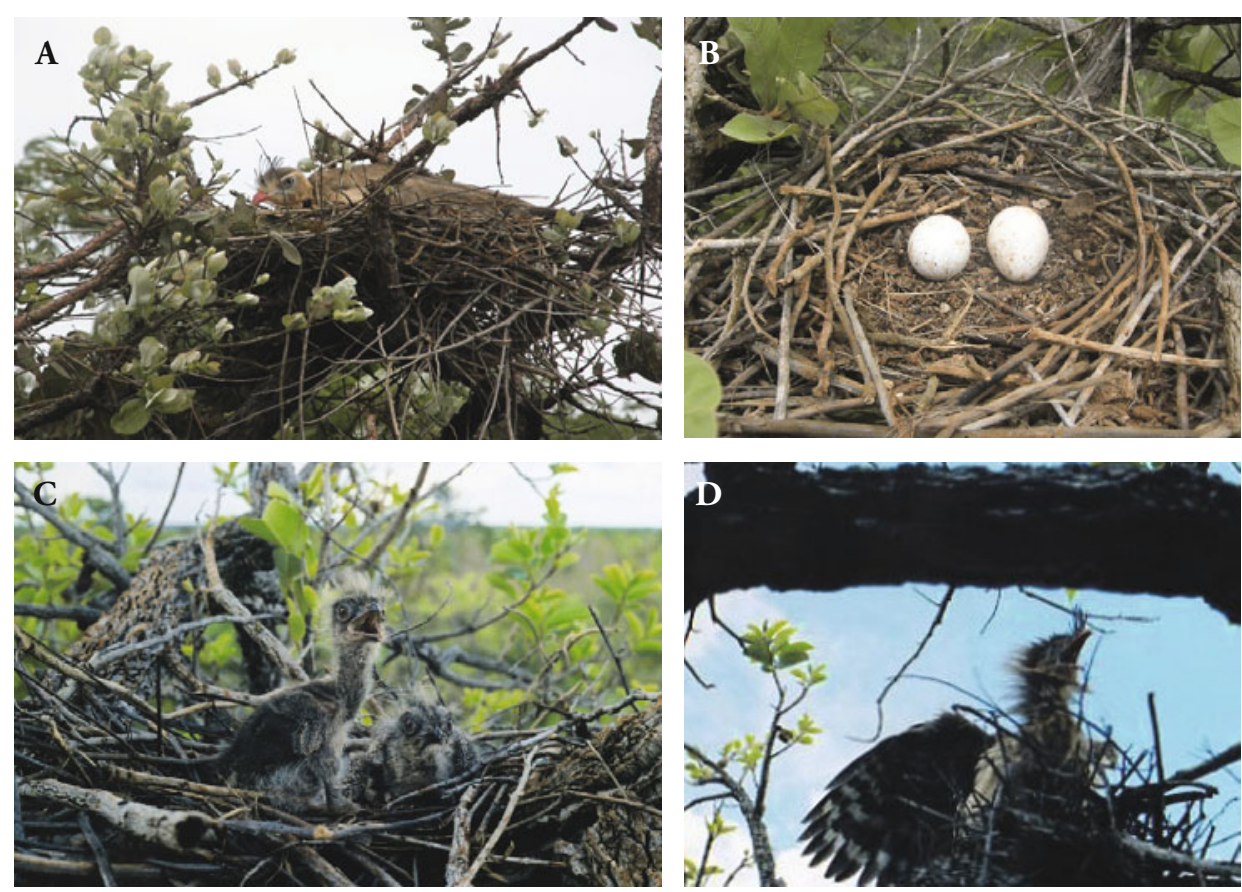

Figure 2. Aspects of the nests, eggs, nestlings and adults of Cariama cristata in woodland firebreaks at Parque Nacional das Emas, central Brazilian Cerrado, during the 2006 breeding season: (A) an adult incubating eggs; (B) two eggs in a nest; (C) two nestlings in a nest; (D) an adult with aggressive behavior in response to the observer's approach.

Table 1. Nest contents, height and distance to park's fence of Reg-legged Seriemas, Cariama cristata, in woodland firebreaks (Campo Cerrado strips managed by fire) at the edge of Parque Nacional das Emas, central Brazil, in October and November 2006.

\begin{tabular}{|c|c|c|}
\hline Distance (m) & Height (m) & Nest content \\
\hline 01 & 2.8 & Two eggs (02 and 10 Oct); two nestlings (12 Oct); empty (14 Nov). \\
\hline 25 & 2.2 & Three eggs (03, 05 and 07 Oct); empty (14 Nov). \\
\hline 12 & 2.3 & Two eggs ( 04,08 and 12 Oct); empty (13 Nov). \\
\hline 74 & 3.8 & Two nestlings (04, 10 and 12 Oct); empty (12 Nov). \\
\hline 20 & 2.4 & Two nestlings (01, 02 and 11 Oct); empty (14 Nov). \\
\hline 38 & 2.6 & Two nestlings (05, 06 and 09 Oct); empty (12 Nov). \\
\hline 08 & 2.9 & Two eggs (02, 04 and 09 Oct); empty (14 Nov). \\
\hline 01 & 2.7 & Two eggs ( 04,06 and 08 Oct); two nestlings ( 11 Oct); empty ( 13 Nov). \\
\hline 10 & 3.2 & Two eggs (04, 07 and 09 Oct); empty (12 Nov). \\
\hline 18 & 2.2 & Two eggs (03 and 07 Oct); two nestlings (08 Oct); empty (14 Nov). \\
\hline 32 & 1.8 & $\begin{array}{l}\text { Adult did not leave the nest ( } 05 \text { Oct); two nestlings ( } 07 \text { and } 10 \text { Oct); empty ( } 12 \\
\text { Nov). }\end{array}$ \\
\hline 22 & 4.3 & $\begin{array}{l}\text { Two eggs (03 Oct); adult did not leave the nest ( } 08 \text { Oct); two nestlings (11 Oct); } \\
\text { empty ( } 11 \text { Nov). }\end{array}$ \\
\hline 54 & 2.7 & $\begin{array}{l}\text { Adult did not leave the nest ( } 02 \text { and } 09 \text { Oct); two nestlings ( } 10 \text { Oct); empty (11 } \\
\text { Nov). }\end{array}$ \\
\hline
\end{tabular}

search period (02-12 October). Similarly, nestlings were found in nests between 01 and 12 October. For four nests, I recorded two nestlings a few days after finding two eggs, indicating egg hatching between 07 and 12 October. The number of eggs and nestlings found per nest was always the same for the consecutive inspections in October. All nests had no eggs or nestlings in mid-November (Table 1). There was no evidence of nest predation or destruction.

All nests were built on trees. They were up to $74 \mathrm{~m}$ away from the park boundaries, and two nests were nearly on top of the fence (Table 1, Fig. 3B). The mean distance of the nests to the fence was $24.2 \mathrm{~m}(\mathrm{SD}=21.1)$. Nest 

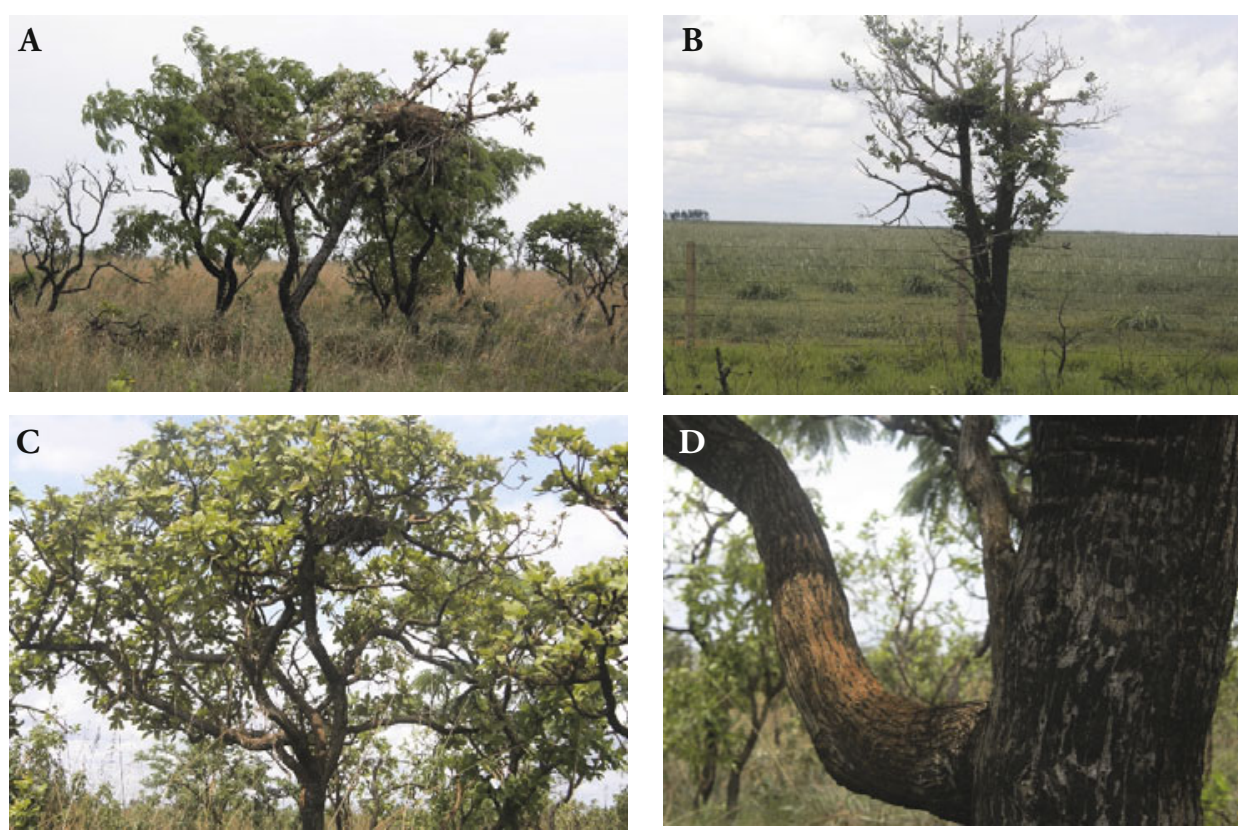

Figure 3. Aspects of the vegetation and nests of Cariama cristata at firebreaks located along the edge of Parque Nacional das Emas, central Brazil, in October 2006: (A) a nest built in the canopy of a small tree located in an area with sparse trees; (B) a nest built nearly over the park's fence adjacent to a pasture; $(\mathbf{C})$ a nest built in a tree canopy in an area with denser woody vegetation; (D) a branch often used by adults to jump to the nest.

height ranged between 1.8 and $4.3 \mathrm{~m}$, with a mean of 2.8 $\mathrm{m}(\mathrm{SD}=0.9)$. Trees that supported the nests could be short with a few branches or tall, highly ramified and with numerous leaves (Fig. 3A, B, C). As nests were built on canopies, adults usually perched on branches and leaves. Some trees had lower branches adults used to jump up to the nest (Fig. 3D). Nine (69\%) nests were in fruiting Pouteria torta (Mart.) (Sapotaceae), one in Piptocarpha rotundifolia (Less.) Baker (Vernonieae) and the others in Annona crassiflora Mart. (Annonaceae). Other plants could not be identified due to missing photographs and branches.

\section{DISCUSSION}

\section{Nest distribution in the study sites}

Nests were found exclusively at edge firebreaks, not been recorded in sites of the other treatments. Their absence in unmanaged Campo Cerrado might be mainly due to factors related to vegetation. Probably, young and adult Seriemas have trouble walking through the dense and tall grassy stratum dominated by fully developed Capim Flexa in unmanaged woodlands. On other hand, frequent controlled fires mean shorter grass, probably favoring mobility and vigilance at the firebreaks.

Further, the two unsealed roads adjacent to managed woodlands could favor nesting on edge firebreaks. Cariama cristata often use the roads in this park (Redford \& Peters 1986), which are important for mobility, especially for the younger birds. Another factor that contributes to choosing boundary firebreaks for nesting is the presence of exotic plantations and cleared areas adjacent to the park, where Seriemas often forage. From November to February, pairs and families expand their home range up to $400-500 \mathrm{~m}$ into soybean plantations and harvested areas adjacent to PNE to search for food resources such as grasshoppers, beetles, rodents, lizards and birds (pers. com.), similarly to that observed for Southern Caracaras, Caracara plancus Miller, 1777 (Tubelis 2019a).

On the other hand, obstacles to establish territories and home ranges, which usually encompass about 20 ha in the Cerrado (Souza et al. 2018), meant there were no nests in the interior firebreaks. Breeding pairs would need to increase their home range to nest in interior firebreaks, as these managed strips were surrounded by an unsuitable matrix marked by high densities of tall Capim Flexa grass. In interior portions of the park, these managed woodlands and adjacent roads usually measure $30 \mathrm{~m}$ and $7 \mathrm{~m}$ in width, respectively. Thus, home ranges would measure about $44 \mathrm{~m}$ in width and $4.5 \mathrm{~km}$ in length to reach 20 ha. Such extremely long home ranges would bring negative consequences for nestling care and foraging efficiency (see Pyke et al. 1977, Tubelis et al. 2004).

The absence of $C$. cristata nests in four treatments most likely did not result from low detectability in tall grasses, since nests are easily seen as large and dark structures in trees. Moreover, in cases of low visibility due to tall grass, the observer occasionally left the vehicle and walked for hundreds of meters on adjacent woodlands. The sampling in this study was enough to discover nests 
in a selection of edge firebreaks. This pattern should not be interpreted as a total dependence on edge firebreaks, but as a general tendency to use managed woodlands that are adjacent to the frontiers of PNE.

\section{Eggs, nestlings, nests and trees}

Clutches with two and three eggs recorded at firebreaks agrees with findings from previous studies (e.g., Redford $\&$ Peters 1986, Almeida 1994), and clutches with one to four eggs were also reported in major reviews regarding the reproduction of Seriemas (e.g., Miranda-Ribeiro 1937, Gonzaga 1996). Redford \& Peters (1986) reported nests found in September and October at PNE. Although in the present study I did not search in September, all nests found at firebreaks had eggs or nestlings in the first half of October. Considering that incubation period lasts a month (Gonzaga 1996), eggs were laid in early September or late August at firebreaks. Thus, breeding activities of the studied Seriemas began during the dry season at PNE. Also in agreement with Redford \& Peters (1986), I found no eggs or nestlings during the second period of inspections (mid-November). As the two periods of observations of this study were separated by nearly 30 days, I cannot be sure whether the absence of nestlings in November represents predation or successful fledging. However, there is no evidence of nest destruction by storms, humans or animals, since as all nests were still in the trees and had no signs of damage in the last period of field activities.

The nest heights at firebreaks are within the range reported in the most recent review on the biology of Seriemas (Gonzaga 1996), which reported nests at heights of 1-5 m. Additionally, the general aspect of the nests, their size and materials were similar to those reported in previous studies (e.g., Miranda-Ribeiro 1937, Redford \& Peters 1986, Almeida 1994).

Seriemas probably consider accessibility as a factor when selecting trees for nesting. Since adults bring vegetal material to the nest on short flights (Almeida 1994, Silva et al. 2016), they may choose tree canopies with a certain branch architecture and amount of leaves to perch, move in the nests during incubation, care for nestlings, and detect potential predators. Moreover, they may prefer trees with one or a few nearly horizontal branches at lower heights for their frequent jumps towards the nest. Pouteria torta, the plant species most frequently used for nesting, appears to provide these advantages for Seriemas. It is abundant in Campo Cerrado firebreaks and its height is like most trees (pers. obs.). This tree was fruiting in October and November, but the fruit was not ripe, so it was probably not attractive for potential omnivorous predators during the Seriemas' nesting period. Previous studies on Seriema breeding have not reported nests in $P$. torta trees (e.g., Redford \& Peters 1986, Almeida 1994, Marini et al. 2012). The literature has not identified a preference for any given species, since few nests were found.

\section{Fire management and conservation issues}

For large mammals conservation, Silveira et al. (1999) recommended a fire management program including rotating controlled fires in different sections of PNE. Additionally, Ramos-Neto \& Pivello (2000) stressed the need for reevaluating policies and management procedures concerning fire in this park. They argued that the natural fire regime benefits biodiversity, since fires started by lightning create mosaics of grassland and woodland patches with different amounts of biomass throughout the park (Ramos-Neto \& Pivello 2000).

My study of $C$. cristata agrees with these two investigations. Natural fires in the rainy season shortened grasses, creating suitable patches of Campo Cerrado woodlands for Seriemas. Similarly, fire management programs can generate such patches (woodlands surrounded by firebreaks) by rotating human-induced fires on several sections of the park. These patches of Campo Cerrado woodland without fully developed Capim Flexa grass would be essential to nest a desirable number of Seriemas inside the park. Although firebreaks mitigate the negative effects of dominant tall Capim Flexa grass, this could lead to negative consequences for Seriemas if this is the sole fire management practice at PNE. Without enough suitable habitat throughout the park, the population of Seriemas will remain concentrated near its boundaries.

\section{ACKNOWLEDGEMENTS}

I thank Universidade Federal Rural do Semi-Árido for logistic support. Mário Barroso Ramos-Neto provided a map of the park. Rogério Souza, from the Instituto Brasileiro de Recursos Naturais e Renováveis (IBAMA), provided a license to study birds at Parque Nacional das Emas. Margarete Naomi Sato identified the plant species. Three anonymous reviewers, Dra. Lilian Manica, Renata Cambraia and Adriano P. Campos made constructive suggestions on an early version of this manuscript. This research was funded by Conselho Nacional de Desenvolvimento Cientifico e Tecnológico/CNPq (proc. 471360/2006-6), Fundação de Amparo à Pesquisa do Estado de São Paulo/FAPESP (process no. 05/00773-3), and Idea Wild. 


\section{REFERENCES}

Almeida A.C.C. 1994. Notas sobre a biologia reprodutiva da Seriema Cariama cristata (Linnaeus, 1766) (Gruiformes-Cariamidae). Revista Nordestina de Biologia 9: 49-59.

Antas P.T.Z. \& Cavalcanti R.B. 1988. Aves comuns do Planalto Central. Brasília: Universidade de Brasília.

Assad E.D. 1994. Chuva nos Cerrados: análise e espacialização. Brasília: EMBRAPA/SPI.

Bardsley D.K., Prowse T.A.A. \& Siegfriedt C. 2019. Seeking knowledge of traditional indigenous burning practices to inform regional bushfire management. Local Environment 24: 727-745.

Brooks D.M. 2014. Ecological notes on seriema species in the Paraguayan Chaco, with observations on Chunga biology. Revista Brasileira de Ornitologia 22: 234-237.

Cavalcanti R.B. \& Alves M.A.S. 1997. Effects of fire on savanna birds in central Brazil. Ornitología Neotropical 8: 85-87.

Cintra R. \& Sanaiotti T.M. 2005. Efeitos do fogo na composição da comunidade de aves em uma Savana amazônica brasileira. Brazilian Journal of Biology 65: 683-695.

Connell J., Watson S.J., Taylor R.S., Avitabile S.C., Schedvin N., Schneider K. \& Clarke M.F. 2019. Future fire scenarios: predicting the effect of fire management strategies on the trajectory of highquality habitat for threatened species. Biological Conservation 232: 131-141.

Eiten G. 1972. The Cerrado vegetation of Brazil. Botanical Review 38: 205-341.

Eiten G. 1993. Vegetação do Cerrado, p. 17-73. In: Pinto M.N. (ed.). Cerrado: caracterização, ocupaçâo e perspectivas. Brasília: Universidade de Brasília.

França H., Ramos-Neto M.B. \& Setzer A. 2007. O fogo no Parque Nacional das Emas. Brasília: Ministério do Meio Ambiente.

Fry C.H. 1970. Ecological distribution of birds in north-eastern Mato Grosso state, Brazil. Anais da Academia Brasileira de Ciências 42: 275-318.

Gonzaga L.P. 1996. Family Cariamidae (seriemas), p. 234-239. In: del Hoyo J., Elliott A. \& Sargatal J. (eds.). Handbook of the birds of the world, v. 3 (Hoatzin to auks). Barcelona: Lynx Editions.

Greenberg C.H., Keyser T.L., McNab W.H. \& Scott P. 2019. Breeding bird response to season of burn in an upland hardwood forest. Forest Ecology and Management 449: 117442.

Marinho-Filho J., Rodrigues F.H.G. \& Juarez K.M. 2002. The Cerrado mammals: diversity, ecology and natural history, p. 266-284. In: Oliveira P.S. \& Marquis R.J. (eds.). The Cerrados of Brazil: ecology and natural history of a Neotropical savanna. New York: Columbia University Press.

Marini M.Â., Borges F.J.A., Lopes L.E., Sousa N.O.M., Gressler D.T., Santos L.R., Paiva L.V., Duca C., Manica L.T., Rodrigues S.S., França L.L., Costa P.M., França L.C., Heming N.M., Silveira M.B., Pereira Z.P., Lobo Y., Medeiros R.C.S. \& Roper J.J. 2012. Breeding biology of birds in the Cerrado of central Brazil. Ornitología Neotropical 23: 385-405.

Miranda H.S., Bustamante M.M.C. \& Miranda A.C. 2002. The fire factor, p. 51-68. In: Oliveira P.S. \& Marquis R.J. (eds.). The cerrados of Brazil: ecology and natural history of a Neotropical savanna. New York: Columbia University Press.

Miranda H.S., Sato M.N., Andrade S.M.A., Haridasan M. \& Morais H.C. 2004. Queimadas no Cerrado: caracterização e impactos, p. 69-123. In: Aguiar L.M.S. \& Camargo A.J.A. (eds.). Cerrado: ecologia e caracterização. Brasília: EMBRAPA.

Miranda H.S., Sato M.N., Nascimento-Neto W. \& Aires F.S. 2009. Fires in the Cerrado, the Brazilian Savana, p. 427-450. In: Cochrane M.A. (ed.). Tropical fire ecology: climate change, land use, and ecosystem dynamics. New York: Springer Praxis.

Miranda-Ribeiro A. 1937. A Seriema. Revista do Museu Paulista 23: 35-90.

Mistry J. 1998. Fire in the Cerrado (savannas) of Brazil: an ecological review. Progress in Physical Geography 22: 425-448.

Oliveira P.S. \& Marquis R.J. (eds.). 2002. The Cerrados of Brazil: ecology and natural history of a Neotropical savanna. New York: Columbia University Press.

Oliveira-Filho A.T. \& Ratter J.A. 2002. Vegetation physiognomies and woody flora of the Cerrado Biome, p. 91-120. In: Oliveira P.S. \& Marquis R.J. (eds.). The Cerrados of Brazil: ecology and natural history of a Neotropical savanna. New York: Columbia University Press.

O'Loughlin L.S., Gooden B., Foster C.N., MacGregor C.I., Catford J.A. \& Lindenmayer D.B. 2019. Invasive shrub re-establishment following management has contrasting effects on biodiversity. Scientific Reports 9: 4083.

Phalan B.T., Northrup J.F., Yang Z., Deal R.L., Rousseau J.S., Spies T.A. \& Betts M.G. 2019. Impacts of the Northwest Forest Plan on forest composition and bird populations. Proceedings of the National Academy of Science of the United States of America 116: 3322-3327.

Pivello V.R. 2006. Fire management for biological conservation in the Brazilian Cerrado, p. 129-154. In: Mistry J. \& Berardi A. (eds.). Savannas and dry forests: linking people with nature. Hants: Ashgate.

Pyke G.H., Pulliam H.R. \& Charnov E.L. 1977. Optimal foraging in a selective review of theory and tests. Quarterly Review of Biology 52: $137-154$.

Ragheb L.H., Miller K.E. \& Kiltie R.A. 2019. Optimizing reproductive opportunity for Florida Grasshopper Sparrows: when to burn? Journal of Wildlife Management 83: 544-555.

Ramos-Neto M.B. \& Pivello V.R. 2000. Lightning fires in a Brazilian Savanna national park: rethinking management strategies. Environmental Management 26: 675-684.

Redford K.H. 1985. Emas National Park and the plight of the Brazilian Cerrados. Oryx 19: 218-214.

Redford K.H. \& Peters G. 1986. Notes on the biology and song of the Red-legged Seriema (Cariama cristata). Journal of Field Ornithology 57: 261-269.

Scariot A., Sousa-Silva J.C. \& Felfili J.M. 2005. Cerrado: ecologia, biodiversidade e conservação. Brasília: Ministério do Meio Ambiente.

Sick H. 1997. Ornitologia brasileira. Rio de Janeiro: Editora Nova Fronteira.

Silva A.N., Nunes R., Estrela D.C., Malafaia G. \& Castro A.L.S. 2016. Behavioral repertoire of the poorly known Red-legged Seriema, Cariama cristata (Cariamiformes: Cariamidae). Revista Brasileira de Ornitologia 24: 73-79.

Silveira L., Jácomo A.T.A., Diniz-Filho J.A.F. \& Rodrigues F.H.G. 1999. Impact of wildfires on the megafauna of Emas National Park, central Brazil. Oryx 33: 108-114.

Souza D.C., Vieira L.D. \& Castro A.L.S. 2018. Territoriality and home range of the Red-legged Seriema (Cariama cristata). Ornitología Neotropical 29: 101-105.

Tubelis D.P. 2009a. Feeding ecology of Ara ararauna (Aves, Psittacidae) at firebreaks in western Cerrado, Brazil. Biotemas 22: 105-115.

Tubelis D.P. 2009b. Bird foraging in Anacardium patches in central Brazilian firebreaks: relationship between flock size and patch size. Ornitología Neotropical 20: 421-430.

Tubelis D.P. 2019a. Aggregations of Southern Caracaras (Caracara plancus) in soybean plantations in central Cerrado, Brazil. Revista Brasileira de Ornitologia 27: 53-55. 
Tubelis D.P. 2019b. Nesting biology of the Aplomado Falcon (Falco femoralis) at Parque Nacional das Emas, central Brazil. Revista Brasileira de Ornitologia 27: 225-229.

Tubelis D.P. \& Delitti W.B.C. 2010. Fire management and the nesting of Athene cunicularia (Aves, Strigidae) in grasslands in central Cerrado, Brazil. Biota Neotropica 10: 93-101.

Tubelis D.P., Lindenmayer D.B. \& Cowling A. 2004. Novel patch- matrix interactions: patch width influences matrix use by birds. Oikos 107: 634-644.

Zlonis E.J., Walton N.G., Sturtevant B.R., Wolter P.T. \& Niemi G.J. 2019. Burn severity and heterogeneity mediate avian response to wildfire in a hemiboreal forest. Forest Ecology and Management 439: 70-80.

Associate Editor: Lilian T. Manica. 